\title{
INFLUENGE OF CLOVER CONTENT OF MIXED LEY ON MAGNESIUM AND POTASSIUM IN RED CLOVER AND TIMOTHY
}

\author{
RAILI JOKINEN \\ University of Helsinki, Department of Agricultural Chemistry
}

Received October 1, 1968

Several authors (Mattson et al. 1949, Elgabaly and Wiklander 1949, Williams and Coleman 1950, McLean and Baker 1953, Smith and Wallace 1956) have claimed that the ratio between inorganic cations taken up by plants will depend on the ability of plant roots to absorb or to adsorb monovalent and divalent cations according to the Donnanprinciple. The inherent differences between plant species, the properties of culture medium etc., also have a marked effect on the cation uptake (МеHLICH 1953, ULRICH 1961, BARBER 1966, Oliver and Barber 1966, Devlin 1966, Henricks 1966, Oberländer 1966, Mengel 1968). Between associated species Drake et al. (1951), Gray et al. (1953) and Mouat and WALKer (1959 a, 1959 b) have observed competition for cations. According to SALONEN and Hirvola (1963) and Raininko (1968) the mineral content of clover was in mixed leys slightly lower than in pure clover stands.

In the present work an attempt is made to study whether the clover content of red clover-timothy ley may have any effect on the total contents of magnesium and potassium and on the ratios $\mathrm{K} / \mathrm{Mg}, \mathrm{Ca} / \mathrm{Mg}, \mathrm{Ca}+\mathrm{Mg} / \mathrm{K}+\mathrm{Na}$ in clover and in timothy. The effect of the respective properties of the soil is also taken into account.

\section{Materials and methods}

The plant material used in this study was collected from red clover-timothy leys on 90 farms in the years 1966 and 1967. The samples were taken at a distance of 5-15 km one after the other from farms in Southwest Finland, Satakunta and South Ostrobothnia. The total yield of an area of $50 \times 50 \mathrm{~cm}^{2}$ was collected. Soil samples were taken at the same time and from the same place as the plant samples.

The botanical composition of air-dried hay samples (90-93\% dry matter) was determined. In addition to red clover and timothy the samples contained $0-70 \%$ (an average 
of $16 \pm 4 \%$ ) other grasses, mainly tufted hairgrass and common bentgrass, and $0-33 \%$ (an average of $6 \pm 2 \%$ ) weeds (dandelion, sorrel, scentless mayweed etc.). There was no clover in 18 samples and no timothy in 1 sample. The clover and timothy were analysed separately. The dry matter content was determined on $2 \mathrm{~g}$ subsamples dried at $130^{\circ} \mathrm{C}$ for $11 / 2$ hours, subsequently the wet combustion was carried out with a mixture of sulphuric acid, nitric acid and percloric acid (1:2.5: 15) according to the method of ScHARRER and Munk (1956). Calcium and magnesium were determined with atomic absorption spectrophotometer Perkin Elmer 290 using $\mathrm{La}_{2} \mathrm{O}_{3}$ as a buffer. Potassium and sodium were determined with an EEL flame photometer.

The soil samples were air-dried and ground to pass a $2 \mathrm{~mm}$ sieve. The exchangeable cations were extracted with $\mathrm{N} \mathrm{NH}_{4} \mathrm{OAc}$, at $\mathrm{pH}$ 7, and the calcium, magnesium, potassium and sodium contents of the leachate were determined as in plant analyses, except that $\mathrm{SrCl}_{2}$ was used as the buffer instead of $\mathrm{La}_{2} \mathrm{O}_{3}$. The hydrogen ion content was estimated by titration of an aliquot of the extract to $\mathrm{pH} 7$ using a Beckman Zeromatic pH-meter. The cation exchange capacity was calculated as the sum of calcium, magnesium, potassium, sodium and hydrogen, and the $\mathrm{Mg}$ - and $\mathrm{K}$-saturation as a percentage of this value (ScHOLLenberger and Simon 1945). The $\mathrm{pH}$ of soil samples was measured in the $0.01 \mathrm{M} \mathrm{CaCl}_{2}$

Table 1. Exchangeable cations in the soil samples.

\begin{tabular}{|c|c|c|c|c|}
\hline & \multicolumn{2}{|c|}{ Clover } & \multicolumn{2}{|c|}{ Timothy } \\
\hline & $\left.\operatorname{Mean}^{1}\right)$ & Range & $\left.\operatorname{Mean}^{1}\right)$ & Range \\
\hline $\mathrm{pH}\left(\mathrm{CaCl}_{2}\right)$ & $5.08 \pm 0.14$ & $4.09-6.64$ & $5.01 \pm 0.14$ & $3.70-6.64$ \\
\hline CEC me $/ 100 \mathrm{~g}$ & $19.26 \pm 2.13$ & $9.21-66.88$ & $21.50 \pm 1.81$ & $9.21-66.88$ \\
\hline $\mathrm{Ca}$ saturation \% & $43.14 \pm 4.05$ & $12.5-90.7$ & $40.87 \pm 3.77$ & $6.1-90.7$ \\
\hline $\mathrm{Mg} \quad »$ & $8.90 \pm 1.55$ & $1.0-29.5$ & $8.45 \pm 1.34$ & $1.0-29.5$ \\
\hline K $\quad 》$ & $1.62 \pm 0.24$ & $0.3-4.9$ & $1.68 \pm 0.24$ & $0.3-6.1$ \\
\hline $\mathrm{K} / \mathrm{Mg}$ & $0.24 \pm 0.04$ & $0.02-0.93$ & $0.29 \pm 0.09$ & $0.02-3.03$ \\
\hline $\mathrm{Ca} / \mathrm{Mg}$ & $7.89 \pm 1.69$ & $1.63-34.24$ & $7.60 \pm 1.39$ & $1.63-34.24$ \\
\hline $\mathrm{Ca}+\mathrm{Mg} / \mathrm{K}+\mathrm{Na}$ & $23.40 \pm 2.80$ & $5.62-58.85$ & $22.19 \pm 2.39$ & $5.17-58.85$ \\
\hline
\end{tabular}

1 with confidence limits at $5 \%$ level.

suspension in a ratio of 1: 2.5 of soil to solution (RYTI 1965). Table 1 shows the results of these analyses separately for the 72 soils growing clover and for the 89 soils growing timothy, as means with confidence limits at $5 \%$ level and as the range. Further, Table 1 presents the ratios of the exchangeable cations $\mathrm{K} / \mathrm{Mg}, \mathrm{Ca} / \mathrm{Mg}$ and $\mathrm{Ca}+\mathrm{Mg} / \mathrm{K}+\mathrm{Na}$ on the equivalent basis. The variation in most of these characteristics in fairly large, but within the limits established for Finnish soil samples.

In 1966 and 1967 the weather conditions were alike in the beginning of the growing season: June and the beginning of July were warm and fairly dry. The samples were collected between the 4 th and the 9 th of July.

The material was divided into three groups according to the age of the ley: (those of the) 1st year, 2nd year and 3rd year or older leys. 


\section{Results}

The properties of clover and timothy in Tables 2 and 3, respectively, are recorded as the means with confidence limits at $5 \%$ level and as the ranges. In this study the data on the contents and ratios of cations in plants present the results of total analyses. The magnesium and potassium contents are given in $\mathrm{mg} / \mathrm{g}$ and the ratios of $\mathrm{K} / \mathrm{Mg}, \mathrm{Ca} / \mathrm{Mg}$, and $\mathrm{Ca}+\mathrm{Mg} / \mathrm{K}+\mathrm{Na}$ on the equivalent basis. The results agree with the total ash analyses reported by MÄKELÄ (1967), considering the fact that the samples of this investigation were collected after the blooming state of timothy and before that of red clover.

Table 2. Calcium, magnesium and potassium contents and cation ratios in clover.

\begin{tabular}{|c|c|c|c|c|c|c|c|c|}
\hline ey & $\begin{array}{c}\text { Number } \\
\text { of } \\
\text { samples }\end{array}$ & $\begin{array}{c}\text { Clover } \\
\text { in ley } \\
\%\end{array}$ & $\begin{array}{c}\mathrm{Ca} \\
\mathrm{mg} / \mathrm{g}\end{array}$ & $\begin{array}{l}\mathrm{Mg} \\
\mathrm{mg} / \mathrm{g}\end{array}$ & $\begin{array}{c}\mathrm{K} \\
\mathrm{mg} / \mathrm{g}\end{array}$ & $\frac{\mathrm{K}}{\mathrm{Mg}}$ & $\frac{\mathrm{Ca}}{\mathrm{Mg}}$ & $\frac{\mathrm{Ca}+\mathrm{Mg}}{\mathrm{K}+\mathrm{Na}}$ \\
\hline st & 18 & $\begin{array}{r}35 \pm 12 \\
1-89\end{array}$ & $\begin{array}{r}15.23 \pm 1.60 \\
9.91-21.90\end{array}$ & $\begin{array}{l}3.89 \pm 0.71 \\
2.22-8.64\end{array}$ & $\begin{array}{r}22.33 \pm 3.76 \\
8.30-34.89\end{array}$ & $\begin{array}{l}2.05 \pm 0.50 \\
0.38-3.74\end{array}$ & $\begin{array}{l}2.85 \pm 0.45 \\
1.32-4.56\end{array}$ & $\begin{array}{l}2.26 \pm 0.69 \\
0.95-5.92\end{array}$ \\
\hline 2nd & 23 & $\begin{array}{r}20 \pm 7 \\
1 \leq 73\end{array}$ & $\begin{array}{l}17.91 \pm 2.07 \\
12.58-28.49\end{array}$ & $\begin{array}{l}4.01 \pm 0.55 \\
2.12-6.37\end{array}$ & $\begin{array}{r}20.37 \pm 3.07 \\
5.73-34.57\end{array}$ & $\begin{array}{l}1.80 \pm 0.39 \\
0.28-4.04\end{array}$ & $\begin{array}{l}3.09 \pm 0.72 \\
1.40-8.17\end{array}$ & $\begin{array}{l}2.82 \pm 0.83 \\
1.19-9.08\end{array}$ \\
\hline 3rd - & 31 & $\begin{array}{r}13 \pm 5 \\
1-52\end{array}$ & $\begin{array}{l}18.84 \pm 2.81 \\
10.27-49.05\end{array}$ & $\begin{array}{l}3.79 \pm 0.39 \\
1.94-6.08\end{array}$ & $\begin{array}{r}20.79 \pm 2.94 \\
6.95-38.75\end{array}$ & $\begin{array}{l}1.92 \pm 0.35 \\
0.37-3.72\end{array}$ & $\begin{array}{l}3.00 \pm 0.49 \\
1.69-6.93\end{array}$ & $\begin{array}{l}3.18 \pm 0.89 \\
1.09-12.13\end{array}$ \\
\hline 11 & 72 & $\begin{array}{r}21 \pm 5 \\
1-89\end{array}$ & $\begin{array}{r}17.64 \pm 1.42 \\
9.91-49.05\end{array}$ & $\begin{array}{l}3.89 \pm 0.29 \\
1.94-8.64\end{array}$ & $\begin{array}{r}21.04 \pm 1.78 \\
5.73-38.75\end{array}$ & $\begin{array}{l}1.93 \pm 0.21 \\
0.28-4.04\end{array}$ & $\begin{array}{l}3.00 \pm 0.32 \\
1.32-8.17\end{array}$ & $\begin{array}{l}2.76 \pm 0.48 \\
0.95-12.13\end{array}$ \\
\hline
\end{tabular}

Table 3. Calcium, magnesium and potassium contents and cation ratios in timothy.

\begin{tabular}{|c|c|c|c|c|c|c|c|c|c|}
\hline Ley I & $\begin{array}{c}\text { Number } \\
\text { of } \\
\text { samples }\end{array}$ & $\begin{array}{c}\text { Clover } \\
\text { in ley } \\
\%\end{array}$ & $\begin{array}{c}\mathrm{Ca} \\
\mathrm{mg} / \mathrm{g}\end{array}$ & $\begin{array}{l}\mathrm{Mg} \\
\mathrm{mg} / \mathrm{g}\end{array}$ & $\begin{array}{c}\mathrm{K} \\
\mathrm{mg} / \mathrm{g}\end{array}$ & $\frac{\mathrm{K}}{\mathrm{Mg}}$ & & $\frac{\mathrm{Ca}}{\mathrm{Mg}}$ & $\frac{\mathrm{Ca}+\mathrm{Mg}}{\mathrm{K}+\mathrm{Na}}$ \\
\hline 1st & 23 & $\begin{array}{r}24 \pm 10 \\
0-65\end{array}$ & $\begin{array}{c}2.48 \pm 0.33 \\
1.11-4.24\end{array}$ & $\begin{array}{l}1.16 \pm 0.14 \\
0.56-1.74\end{array}$ & $\begin{array}{c}20.50 \pm 1.75 \\
10.82-27.45\end{array}$ & $\begin{array}{l}6.04 \pm 1 \\
2.47-\end{array}$ & $\begin{array}{l}1.09 \\
12.19\end{array}$ & $\begin{array}{l}1.34 \pm 0.19 \\
0.71-2.47\end{array}$ & $\begin{array}{l}0.44 \pm 0.08 \\
0.25-1.09\end{array}$ \\
\hline 2nd & 30 & $\begin{array}{r}15 \pm 6 \\
0-73\end{array}$ & $\begin{array}{l}2.54 \pm 0.25 \\
1.39-4.65\end{array}$ & $\begin{array}{l}1.14 \pm 0.11 \\
0.75-1.89\end{array}$ & $\begin{array}{l}19.26 \pm 1.39 \\
10.73-29.17\end{array}$ & $\begin{array}{l}5.50 \pm \\
2.13-\end{array}$ & $\begin{array}{l}0.52 \\
7.65\end{array}$ & $\begin{array}{l}1.40 \pm 0.16 \\
0.82-2.73\end{array}$ & $\begin{array}{l}0.47 \pm 0.06 \\
0.28-1.03\end{array}$ \\
\hline $3 \mathrm{rd}-$ & 36 & $\begin{array}{r}11 \pm 4 \\
0-52\end{array}$ & $\begin{array}{l}2.59 \pm 0.24 \\
1.32-5.30\end{array}$ & $\begin{array}{l}1.15+0.10 \\
0.73-1.90\end{array}$ & $\begin{array}{l}18.76 \pm 1.32 \\
11.31-27.34\end{array}$ & $\begin{array}{l}5.36 \pm \\
2.16-\end{array}$ & $\begin{array}{l}0.54 \\
7.89\end{array}$ & $\begin{array}{l}1.40 \pm 0.13 \\
0.86-2.23\end{array}$ & $\begin{array}{l}0.50 \pm 0.07 \\
0.38-1.28\end{array}$ \\
\hline All & 89 & $\begin{array}{r}16 \pm 4 \\
0-73\end{array}$ & $\begin{array}{l}2.53 \pm 0.15 \\
1.11-5.30\end{array}$ & $\begin{array}{l}1.15 \pm 0.06 \\
0.56-1.90\end{array}$ & $\begin{array}{r}19.38 \pm 0.82 \\
10.73-29.17\end{array}$ & $\begin{array}{l}5.58 \pm \\
2.13-1\end{array}$ & $\begin{array}{r}0.38 \\
12.91\end{array}$ & $\begin{array}{l}1.39 \pm 0.06 \\
0.71-2.73\end{array}$ & $\begin{array}{l}0.47 \pm 0.04 \\
0.25-1.28\end{array}$ \\
\hline
\end{tabular}


The respective coefficients of the simple and partial correlations between the contents of total magnesium or potassium or the ratios of $\mathrm{K} / \mathrm{Mg}, \mathrm{Ca} / \mathrm{Mg}, \mathrm{Ca}+\mathrm{Mg} / \mathrm{K}+\mathrm{Na}$ in clover and timothy $\left(\mathrm{X}_{1}\right)$, the clover content of mixed ley $\left(\mathrm{X}_{2}\right)$, and the magnesium or potassium saturation percentages or the ratios of exchangeable cations on the equivalent basis of $\mathrm{K} / \mathrm{Mg}, \mathrm{Ca} / \mathrm{Mg}, \mathrm{Ca}+\mathrm{Mg} / \mathrm{K}+\mathrm{Na}$ in soil $\left(\mathrm{X}_{3}\right)$ for leys of different age are summarized in Table 4. These results indicate that the potassium content and the ratios of $\mathrm{K} / \mathrm{Mg}$ and $\mathrm{Ca}+\mathrm{Mg} / \mathrm{K}+\mathrm{Na}$ in clover were fairly closely correlated with the clover content of the first year mixed ley, whereas their correlations with the potassium saturation percentages or the ratios of exchangeable cations $\mathrm{K} / \mathrm{Mg}$ or $\mathrm{Ca}+\mathrm{Mg} / \mathrm{K}+\mathrm{Na}$ in the soil were not significant. The former relationships remained almost unchanged when the effect of the soil properties was eliminated. The low negative correlation between the magnesium content in clover and the clover content of ley grew closer when the magnesium saturation percentage of the soil was taken into consideration. According to the simple correlation coefficients in the 2nd year and older leys, the effect of the clover content on the magnesium and potassium contents and on the ratios of cations in clover was not significant, whereas the influence of the soil properties was more marked.

The magnesium and potassium contents and the ratios of the cations in timothy were not significantly dependent on the clover content of the leys. In this respect the variations in the soil properties seemed to have a more pronounced effect in leys of all ages.

In this material the magnesium and potassium contents and the ratios of the cations in clover of the first year ley $\left(\mathrm{X}_{1}\right)$ were dependent on the clover content of the ley $\left(\mathrm{X}_{2}\right)$, and on the magnesium or potassium saturation percentages, or on the ratios of the exchangeable cations in the soil $\left(\mathrm{X}_{3}\right)$ according to the following equations of regression:

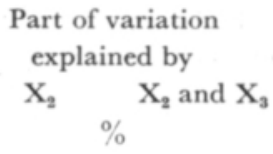

$\begin{array}{llrr}\mathrm{Mg} \mathrm{mg} / \mathrm{g} & =3.68-0.04 \mathrm{X}_{2}+0.15 \mathrm{X}_{3} & 12 & 45 \\ \mathrm{~K} " & =9.45+0.12 \mathrm{X}_{2}+3.92 \mathrm{X}_{3} & 43 & 49 \\ \mathrm{~K} / \mathrm{Mg} & =0.31+0.03 \mathrm{X}_{2}+2.83 \mathrm{X}_{3} & 36 & 76 \\ \mathrm{Ca} / \mathrm{Mg} & =0.17+0.01 \mathrm{X}_{2}+0.08 \mathrm{X}_{3} & 0 & 1 \\ \mathrm{Ca}+\mathrm{Mg} / \mathrm{K}+\mathrm{Na} & =2.92-0.03 \mathrm{X}_{2}+0.02 \mathrm{X}_{3} & 43 & 49\end{array}$

In this relatively small material about $43 \%$ of the variations in the potassium content and in the $\mathrm{Ca}+\mathrm{Mg} / \mathrm{K}+\mathrm{Na}$ ratio in clover from the first year ley were caused by variations in the clover content of the mixed ley, and about $49 \%$ by variations in both independent variables. About $36 \%$ of the variation in the ratio $\mathrm{K} / \mathrm{Mg}$ was explained by the clover content, and about $76 \%$ by the ratio $\mathrm{K} / \mathrm{Mg}$ of the exchangeable cations of soil together with the clover content.

\section{Discussion}

The effect of the age of ley on the magnesium and potassium contents and on the ratio of $\mathrm{K} / \mathrm{Mg}$ in clover seemed to be rather small. The magnesium content did not vary regularly, but the potassium content seemed to decrease with the age of the ley. The ratio 


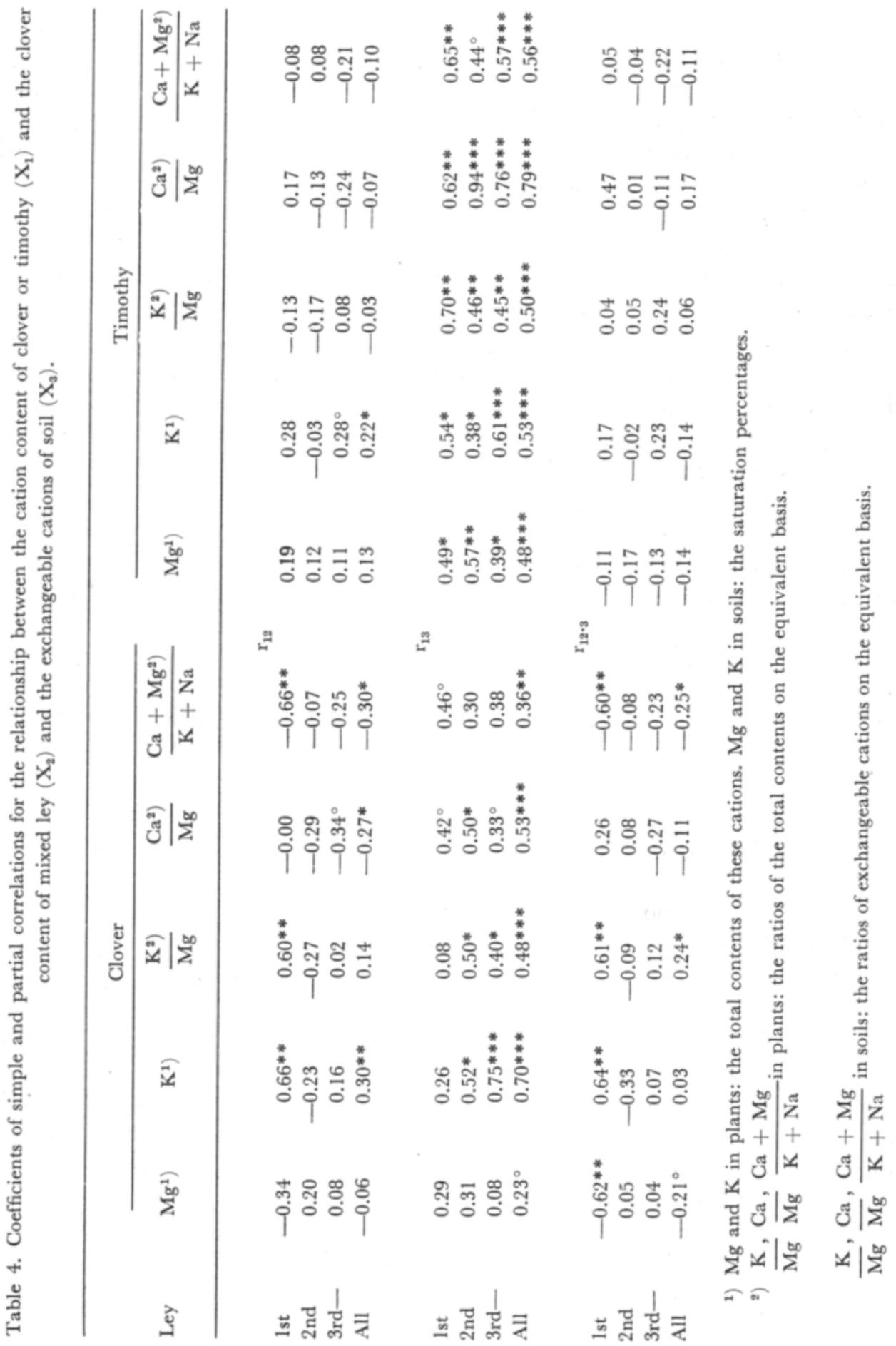


between monovalent and divalent cations in clover changed with the age of the ley. The sodium content of the plants was so small that its effect on this ratio was of no importance. In this material the magnesium and potassium contents and the ratios of $\mathrm{Ca} / \mathrm{Mg}$ and $\mathrm{Ca}+\mathrm{Mg} / \mathrm{K}+\mathrm{Na}$ in timothy did not vary at all with the age of ley. The potassium content and the ratio of $\mathrm{K} / \mathrm{Mg}$ were somewhat higher in the older leys.

In the first year ley the potassium content of clover $\left(\mathrm{X}_{1}\right)$ was fairly closely correlated with the clover content of the ley $\left(\mathrm{X}_{2}\right)\left(\mathrm{r}_{12}=0.66^{* *}\right)$, and the correlation was not diminished when the potassium saturation rate of the soil $\left(\mathrm{X}_{3}\right)$ was taken into consideration $\left(r_{12.3}=0.64^{* *}\right)$. DraKe et al. (1951) and GreY et al. (1953) have observed that clover and grasses compete in mixed cultures with each other for potassium because of differences in the CEC of the roots of these plants. According to SAlonen and Hirvola (1963) the potassium content of clover in leys harvested at silage stage was higher when grown alone than when grown with meadow-fescue. The present material indicated that if the potassium saturation in the soil is held constant, the potassium content in clover of a first year ley increases by $0.12 \mathrm{mg} / \mathrm{g}$ when the clover content of the mixed ley increases by $1 \%$. On the other hand, if the clover content is held constant, the potassium content in clover increases by $3.92 \mathrm{mg} / \mathrm{g}$ when the potassium saturation percent in soil increases by $1 \%$. Variations in both of the independent variables simultaneously explained $49 \%$ of the variations in the potassium content of clover.

According to Raininko (1968), timothy does not markedly limit the growth of red clover; however, in the present material it seemed to decrease the potassium content of clover. The competition between clover and grasses for potassium may possibly be due, in addition to the CEC of the roots of plants, to the competition for binding sites on carrier complexes that transport ions from outer to inner space of the roots. The binding sites of a carrier may also be specialized in carrying only one kind of ions or certain ions (MENGEL 1961, Devlin 1966). Barber (1966) demonstrated that a considerable amount of potassium in the plant is taken up by diffusion. The lowering effect of timothy on the potassium content of clover may also be attributed to the fact that grasses grow more rapidly than clover and take up potassium readily when the degree of potassium saturation in soil is high.

RaININKo (1968) found that nitrogen fertilization increased the competitive ability of grasses in relation to clover. Although the influence on the potassium content in clover was not so high, the potassium content of grasses increased significantly (SALONEN and HiIvola 1963, Heinonen 1964). In this material competition between clover and timothy for potassium was found only in the first year leys and, seemed to occur only at an early stage of development of the plants.

The magnesium content of clover in the first year ley $\left(\mathrm{X}_{1}\right)$ showed a poor negative correlation with the clover content of the ley $\left(\mathrm{X}_{2}\right)\left(\mathrm{r}_{12}=-0.34\right)$ and a poor positive correlation with the magnesium saturation of the soil $\left(\mathrm{X}_{3}\right)\left(\mathrm{r}_{13}=0.29\right)$. However, when the magnesium saturation percentage in the soil was taken into consideration, the lowering effect of the clover content of the ley on the magnesium content of clover markedly increased $\left(\mathrm{r}_{12.3}=-0.62^{* *}\right)$. In the 2 nd year and older leys the influence of the soil properties or other factors not investigated in this connection, on the magnesium content of clover was of greater importance.

The ratio of $\mathrm{K} / \mathrm{Mg}$ in clover $\left(\mathrm{X}_{1}\right)$ seemed to increase when the clover content of the 
ley $\left(\mathrm{X}_{2}\right)$ increased $\left(\mathrm{r}_{12}=0.60^{* *}, \mathrm{r}_{12.3}=0.61^{* *}\right)$. The antagonism between potassium and magnesium appeared under these circumstances more markedly when the potassium uptake of clover increased. Competition between potassium and magnesium increased when the competition for potassium between the plant species decreased. In this material variations in the clover content of the ley explained $36 \%$ of the variation in the ratio of $\mathrm{K} / \mathrm{Mg}$ of clover (first year ley), and, together with the ratio on the equivalent basis of exchangeable cations $\mathrm{K} / \mathrm{Mg}$ in the soil, $76 \%$ of the variation.

There was no correlation between the ratio of $\mathrm{Ca} / \mathrm{Mg}$ in clover and the clove content of the ley $\left(r_{12}=-0.004\right)$, but the relationship with the corresponding ratio of exchangeable cations in the soil was slightly positive $\left(r_{13}=0.42^{\circ}\right)$. In older leys the clover seems to take up more calcium in relation to magnesium than in younger leys (Table 2). The independent variables explained only $1 \%$ of the variation in the ratio of $\mathrm{Ca} / \mathrm{Mg}$. The age of ley seems to have a greater effect on this ratio than any of the factors investigated.

According to this material the ratio of $\mathrm{Ca}+\mathrm{Mg} / \mathrm{K}+\mathrm{Na}$ in the clover of the first year ley $\left(\mathrm{X}_{1}\right)$ was significantly negatively correlated with the amount of clover in the ley $\left(\mathrm{X}_{2}\right)\left(\mathrm{r}_{12}=-0.66^{* *}\right)$ even if the effect of the ratio of the same exchangeable cations in the soil was taken into account $\left(\mathrm{r}_{12.3}=-0.60^{* *}\right)$. Simple correlation between the ratios of $\mathrm{Ca}+\mathrm{Mg} / \mathrm{K}+\mathrm{Na}$ in soil and in clover was low, but positive. In leys with a high content of clover the increased potassium uptake seemed to hamper the absorption of divalent cations by clover. Competition between timothy and clover for monovalent and divalent cations can partly account for the differences in the cation content of clover.

Influence of the clover content of the ley on all the investigated properties of timothy was of minor importance. The properties of the soil had a more decisive effect on the cation composition of timothy. According to tests made by RaInINKo (1968), the nitrogen fertilization increased, among other things, the potassium and magnesium contents and sometimes also the calcium content of grasses. Hernonen (1964) reported that $10-25 \%$ of the variations in the mineral content of timothy were due to variations in weather conditions, in the mean temperature in June, and the precipitation in May and June.

\section{Su $m$ m ary}

The plant and soil material of this study were collected at a distance of 5-15 km one after the other from 90 farms in Southwest Finland, Satakunta and Ostrobothnia in the years $1966-67$.

The coefficients of simple and partial correlations between the contents of total magnesium or potassium or the ratios of $\mathrm{K} / \mathrm{Mg}, \mathrm{Ca} / \mathrm{Mg}, \mathrm{Ca}+\mathrm{Mg} / \mathrm{K}+\mathrm{Na}$ in clover or timothy, the clover content of mixed ley, and the exchangeable cations or their ratios in soil were calculated separately for 1st year, 2nd year, and 3rd year or older leys. The results indicated that according to this rather limited material the potassium content and the ratio $\mathrm{K} / \mathrm{Mg}$ in clover increased and the magnesium content and the ratio $\mathrm{Ca}+\mathrm{Mg} / \mathrm{K}+\mathrm{Na}$ decreased significantly with the increasing clover content of the first year leys, even if the effects of the corresponding exchangeable cations and ratios in soil were taken into consideration. Clover and timothy in mixed ley possibly compete with each other for cations. Cation ratios and the cation content of timothy seemed to be independent of the clover content 
of the mixed ley, the properties of clover in 2nd year and older leys were likewise not dependent on it.

Variations up to $43 \%$ in the magnesium and potassium contents and the cation ratios of clover in first year leys were explained by vatiations in their clover content, and when the exchangeable cations of soil were also taken into account, from 1 to $76 \%$ of this variation could be explained.

ACKNOWLEDGEMENTS. This paper which forms part of an investigation carried out in the University of Helsinki, Department of Agricultural Chemistry, was made possible by a grant from the August Johannes ja Aino Tiuran Maatalouden Tutkimussäätiö, which I wish to acknowledge with sincere gratitude.

\section{REFERENCES}

BARber, S. A. 1966. The role of root interception, mass-flow and diffusion in regulating the uptake of ions by plants from soil. I.A.E.A. Technical reports $65: 39-45$.

Devlin, R. M. 1966. Plant physiology. New York 564 p.

Drake, R. S., Vengris, J. and Colby, W. G. 1951. Cation exchange capacity of plant roots. Soil Sci. 72: $139-147$.

Elgabaly, M. M. and Wiklander, L. 1949. Effect of exchange capacity of clay mineral and acidoid content of plant on uptake of sodium and calcium by excised barley and pea root. Ibid. 67: 419 424.

Gray, B., Drake, M., and Colby, Wm. G. 1953. Potassium competition in grass-legume associations as a function of root cation exchange capacity. Soil Sci. Soc. Amer. Proc. 17: 235-239.

Hernonen, H. 1966. Wirkung von Niederschlag und Temperature auf den Mineralstoffgehalt des Timotheeheus. Ann. Agric. Fenn. 3: 55-67.

Hendricks, S. G. 1961. Salt entry into plants. Soil Sci. Soc. Amer. Proc. 30: 1-7.

Mattson, S., Eriksson, E., Vahtras, K., and Williams, E. G. 1949. Phosphate relationships of soil and plant. I. Membrane equilib. a and phosphate uptake. Ann. Agric. Coll. Sveden 16: 457-484.

Mclean, E. O., and Baker, F. E. 1953. Cation activities in systems of plant roots. Soil Sci. Soc. Amer. Proc. 17: 100-102.

MEHLich, A. 1953. Factors affecting adsorption of cations by plant roots. Ibid. 17: 231-234.

Mengel, K. 1961. Die Donnan-Verteilung den Kationen im Freien Raum der Pflanzenwurzel und ihre Bedeutung für die aktive Kationenaufnahme. Z. Pflanzenern. Düng. Bodenk. 95: 240—253.

Mengel, K. 1968. Ernährung und Stoffwechsel der Pflanze. Jena 436 S.

Movat, M. C., and Walker, T. W. 1959 a. Competition for nutrients between grasses and white clover. I. Effect of grass species and nitrogen supply. Plant Soil 11:30-40.

- - 1959b. Competition for nutrients between grasses and white clover. II. Effect of rout cation-exchange capacity and rate of emergence of associated species. Ibid 11: 41-52.

MÄKel.̊, A. 1967. On the water-solubility of plant minerals. J. Sci. Agric. Soc. Finland 39: 166-182.

OBERLÄnder, H. E. 1966. The relative importance of active and passive processes in ion translocation across root tissue (A review). I.A.E.A. Technical reports 65: 101-120.

Oltver, S. \& Barber, S. A. 1966. An evaluation of the mechanisms governing the supply of calcium, magnesium, potassium and sodium to soybean roots. Soil Sci. Soc. Amer. Proc. 30: 82-89.

Raininko, K. 1968. The effect of nitrogen fertilization, irrigation and number of harvestings upon leys established with various seed mixtures. Acta Agric. Fenn. 112

RYtr, R. 1965. On the determination of soil pH. J. Sci. Agric. Soc. Finland 37: 51-60.

SAlonen, M., and Hrvol., S-L. 1963. Typpilannoituksen vaikutus puna-apilan ja nurminadan sadon määrään ja laatuun. Summary: The effect of nitrogen fertilization on the yield and quality of the crop of red clover and meadow fescue. Ann. Agric. Fenn. 2: 136-152. 
Scharrer, K. S., and Munk, H. 1956. Zur Methodik der nassen Veraschung in agrikulturchemischen Analyse. Agrochimica 1: 44-55.

Schollenberger, C. J., and Simon, R. H. 1945. Determination of exchange capacity and exchangeable bases in soil - ammoniumacetate methode. Soil Sci. 59: 13-24.

Smrth, R. L., and WAllace, A. 1956. Cation exchange capacity of roots and its relation to calcium and potassium content of plants. Ibid. 81: 97-109.

Ulrich, B. 1961. Boden und Pflanze. Ihre Wechelbeziehungen in physikalisch-chemischer Betrachtung. Stuttgart $114 \mathrm{~S}$.

Williams, D. E., and Coleman, N. T. 1950. Cation exchange properties of plant root surfaces. Plant Soil 2: $243-256$.

\title{
SELOSTUS
}

\section{ERI-IKÄISTEN NURMIEN APILAPITOISUUDEN VAIKUTUKSESTA APILAN JA TIMOTEIN MAGNESIUM- JA KALIUMPITOISUUTEEN SEKÄ KATIONIEN SUHTEISIIN}

\author{
RAILI JOKINEN
}

\section{Maanviljelyskemian laitos, Helsingin yliopisto}

Tutkimuksen heinä- ja maanäyteaineisto kerättiin 90 eri talousviljelmältä (5-15 km välein) VarsinaisSuomen, Satakunnan ja Etelä-Pohjanmaan alueilta vuosina 1966-67. Tutkittujen maanäytteiden ominaisuuksia esitetään taulukossa 1. Apila- ja timoteinäytteiden magnesium- ja kaliumpitoisuudet ja kationien suhteet näkyvät taulukoista 2 ja 3 .

Apilan ja timotein sisältämien magnesiumin ja kaliumin kokonaismäärien ja kationien ekvivalentti suhteiden $\left(\mathrm{X}_{1}\right)$, sekakasvuston apilapitoisuuden $\left(\mathrm{X}_{2}\right)$ ja maan magnesium- ja kaliumkyllästysasteen ja vaihtuvien kationien ekvivalentti suhteiden $\left(\mathrm{X}_{\mathbf{3}}\right)$ väliset parittaiset ja osittaiskorrelaatio kertoimet laskettiin erikseen 1. v., 2. v. sekä 3. v. ja sitä vanhemmille nurmille. Tuloksista ilmeni, että tässä verraten pienessä aineistossa ensimmäisen vuoden nurmien apilan kaliumpitoisuus ja suhteen $\mathrm{K} / \mathrm{Mg}$ arvo nousivat ja magnesiumpitoisuus ja suhteen $\mathrm{Ca}+\mathrm{Mg} / \mathrm{K}+\mathrm{Na}$ arvo laskivat tilastollisesti merkitsevăsti apilan määrän sekakasvustossa lisääntyessä, vaikka maan magnesium- ja kaliumkyllästysasteen tai vaihtuvien kationien ekvivalentti suhteiden vaikutus otettiin huomioon. Apila ja timotei ehkä kilpailevat sekakasvustossa ollessaan kationien saannista. Timotein kationien määrät ja suhteet eivät näyttäneet riippuvan sekakasvuston apilan määrästä eivätkä myöskään kahta vuotta vanhempien nurmien apilan tässä tutkimuksessa käsitellyt ominaisuudet.

Ensimmäisen vuoden nurmien apilan magnesium- ja kaliumpitoisuuksissa ja kationien ekvivalentti suhteissa esiintyvistä vaihteluista pystyi sekakasvuston apilapitoisuus selittämäăn $0-43 \%$ ja yhdessă maan tietyn ominaisuuden vaihtelun kanssa $1-76 \%$. 